International Journal of English Literature and Social Sciences
Vol-6, Issue-3; May-Jun, 2021
Journal Home Page Available: https://ijels.com/
Journal DOI: 10.22161/ijels
Peer-Reviewed Journal

\title{
A struggle to belong: The grappling cases of Israel and
}

\section{India}

\author{
Sagarika Mukhopadhyay*, Anirban Banerjee
}

Masters' Student, Department of International Relations, Jadavpur University, India

*Corresponding author

Received: 07 Feb 2021; Received in revised form: 22 Mar 2021; Accepted: 20 Apr 2021; Available online: 10 May 2021

(C)2021 The Author(s). Published by Infogain Publication. This is an open access article under the CC BY license

(https://creativecommons.org/licenses/by/4.0/).

\begin{abstract}
Citizenship as a concept has always been subjected to serious contention, with scholars trying to reach a comprehensive denotation of the word and has rather been considered a "slippery concept." Aligning with the modern democratic spirit, the article titled as "A struggle to belong: The grappling cases of Israel and India" engages with the key question as to: what is citizenship and how it is posited in both Israel and India? We also bring forth a comprehensive comparative study with similarities and differences of the Law of Return in Israel with the modern-day Citizenship (Amendment) Act in India, exploring the cultural aspect of citizenship and its pivotal role in the process of nation-building. The paper also highlights student movements as well as women moving from mere victims to survivors, beneficiaries to contributors, and objects to agents of change in India with regards to demand for citizenship rights.
\end{abstract}

Keywords-Citizenship Amendment Act, Government, India, Israel, Student.

\section{INTRODUCTION}

Citizenship has been entertained as something that anchors a legal status of membership in a community. This age-old conception has undergone various transformations since the times of Athenian democracy and the Roman Republic. Chantal Mouffe points out that citizenship as a concept depends largely on the type of political community and the kind of society prevalent, no matter the character of the regime. The idea has been reinvigorated time and again to get a hold over the community. With the advent of contemporary times and the emergence of numerous associations, organisations, or communities in civil society 'political citizenship' faces aggravated competition in liberal democracies.

Moreover, present literature regarding citizenship tends to emphasize on the concept of 'self-reliance' and highlights the responsibilities one holds with regards to the contribution a person ought to make to the society rather than apt 'political participation' thus, giving rise to ambiguity regarding the aforementioned sphere. It should also be mentioned that in migration discourse, citizenship acts as a distinct mark between the 'members and outsiders' which are brought to the forefront based on an individual's relation to states. This freedom of movement within the said state and the 'right to re-admission' has become a hallmark of 'modern citizenship.' Bellemy points out that T. H. Marshall and Stein Rokkan put forth the idea of a standardised version regarding the evolution of modern citizenship.(Bellemy, 2008) This account draws on their analysis of the history of West European democracies in the 18th, 19th, and 20th centuries where they comprehended citizenship as the product of state building, the emergence of commercial and industrial society, and the construction of a national consciousness, driven forward by class struggle and war. The international arena has treated citizenship as a mechanism that can control migrants and limit the obligations of a state towards foreigners. Citizenship, repeatedly, has come in handy to keep people out or remove them from a particular state, a problem, forwarded by many scholars as this treatment of 'citizenship' as a 'means to an end' is seen as severely problematic and the demarcation of such differences, control over entry and exit, and the set of rights with relation to political participation awarded solely to citizens act as a constraint. Joseph Carens drew a 
comparison between modern-day citizenship and the one that existed during feudal times in the medieval world explaining that citizenship is assigned at birth, not subject to change irrespective of one's will or effort playing an influential role on a person's life and life chances.

There are three distinguishing dimensions to citizenship. Firstly, they talk about citizenship in the political and legal framework; secondly, it explains the rights and duties attached to it, and finally, it goes on to mention individual practises, dispositions, and identities. Moreover, it is important to note that the sense of 'self-determination' that buds out of citizenship often gives rise to conflict amongst state regarding individuals that are claimed by none as their citizens or probably claimed by many. Several legislations that have been passed by the Governments around the world, like the Law of Return, have exacerbated the issue of statelessness as people have been denied 'asylum' in their own country due to failure of meeting certain demands to prove them truly as 'Jews' and not imposters. Similarly, the Citizenship Act, 1955, a legislation passed by the Indian government was amended on 11 December 2019. This move is also speculated to be a source of massive displacement as the amendment claims anyone who took residence on or before 31 December 2014 is not subject to new laws but post that or someone who is amidst the process of acquiring citizenship from the Indian government is a subject to the new laws. Even in this case, individuals who fail to meet the demarcated factors are required to be proved a legitimate 'citizen' and if proved otherwise will be termed as an 'illegal immigrant.' The work of Georg Jellinek regarding a comparison drawn between negative liberty and positive liberty coupled with a similar typology but derived based on the historiography of citizenship by T. H. Marshall espoused the earliest elements of the respective theory that contends civil rights. It should also be pointed out that the Liberal theories regarding citizenship fail to account for "relational aspects of citizenship" at large.(Marshall \& Bottomore, 1949) Dagger points out that in the Republican theories the 'political community' acts as an intermediary between the state and the mass. However, the duties of citizenship do not unpack itself as a set of responsibilities towards nation building or rather the maintenance of nation state. On the other hand, Communitarian theories view the community as something integral to citizens. Communitarians explain that citizens are rationally placed and have a set of atomised rights and duties.

However, it should be noted that the purpose of this paper is not to assess citizenship on the basis of paradigms of International Relations but to reveal its importance and its usage in two of the most important cases regarding it in the world. The paper takes up a qualitative and descriptive role rather than an active one.

\section{CITIZENSHIP AND ITS IMPACT}

Interest in citizenship has never been higher as it is directly related to global and domestic issues. Historically, citizenship has been linked to the privileges of membership with a particular political community from where a fellow human is allowed to participate on an "equal basis" making the fact that 'citizenship' is almost synonymous to political participation. Democratic citizenship has been claimed to be rare but important. Statistics have shown that approximately around $64 \%$ of the electoral practices around nations are democratic. Moreover, a meagre number of countries have continued their democratic practices for 50 years or more. Although history reveals that the number of democracies has steadily increased since the Second World War, the assemblages of voters have seen a steady decline. The general trend of descent in the electoral sphere cannot be ignored, but it should also be mentioned that although citizens express a certain level of dissatisfaction with their 'democratic arrangement,' they continue to approve of democracy. A survey has revealed that $89 \%$ of US respondents considered democracy as 'good system of government' and $87 \%$ contended it to be the 'best', while in the UK $87 \%$ claimed it as 'good' and 78\% the 'best.'

Citizenship by guaranteeing political participation ensured 'Right to Vote' marking a rise in the importance of the 'social and moral dispositions' showing that rules and regulations do not cover everything but involve a certain amount of coercion. If people would act responsible solely as a result of this, it would entail the creation of a 'police state' which would be detrimental to the concept of citizenship as it aimed to inculcate a sense of 'belonging.' Possession of limited knowledge and the character of fallibility cannot safeguard that humans will not err. For example, highway codes or regulations look into coordination and smooth functioning of traffic. Similarly, the functioning of citizenship and the political environment is not left to conscientious acting as situations may crop up that may turn into something chaotic and unavoidable. Thus, to prevent a chaotic situation certain regulations and participatory activities were put into place that would involve the mass at large and thereby cater to the sustenance of the political environment with 'reciprocal rights and duties.' It is contended that many people apply for citizenship solely for the reason of being able to vote. A Scottish report has brought to light the fact that humans often felt powerless whilst they were a refugee and desperately wanted to be involved in the political process. Few refugees opined that the freedom of a person to vote makes him/her a citizen but as a refugee they do not have such privilege at their disposal. They point out that its 
'relational aspect,' which is an outcome of participation, makes the concept of citizenship more important. There is a feeling of belonging and a sense of importance imparted by this action.

\section{ISRAEL AND CITIZENSHIP}

Citizenship as a concept is a feature that secures an individual's place in an "organised society." Martin Edelman in his writing explains how Israel has claimed itself as a safe haven for Jewish people inviting speculative comprehension of citizenship. He goes on to explain that this was a deliberate move by the government that introduced a number of political arrangements that were meant to deal with this issue. Hence controversies in this sphere have exasperated rather than disappear even after fifty years.(Edelman, 1998) The question "Who is a Jew?" gave rise to unprecedented issues like wildfire that aimed citizens' religion and pitted it against their respective national identity.(Nesis) Furthermore, it needs to be mentioned that citizenship in Israel largely entertains the religious side of the nation as history reveals that until the enlightenment arrived membership amongst the Jewish people were derived from halakhah (Jewish religious laws). Mandatory Palestine ceased to exist with the end of the mandate that sought to establish Israel in 1948. Also, the nation at that time, got hold of the idea of "identity cards or temporary residence permits" as it was devoid of any 'legitimate' citizen. It was on 5 July 1950 that the Knesset (parliament) enacted the Law of Return, specifying "every Jew has the right to come to his country as an Oleh (Jewish immigrant)" but the law remained silent on the issue of citizenship. Post this, the Citizenship Act of 1952 repealed Palestinian Citizenship Order 1925 and explained four ways by which one could possess Israeli nationality: by return; by residence; by birth; and by naturalization. It is necessary to raise the concerns of certain scholars who recognised the fact that there was an absence of definition regarding who constituted 'Jews' and that the end of Palestine mandate left the Arab residents in a pool of uncertainty as they were not seen as "natural citizens of Israel." Arabs were granted citizenship only if they fulfilled certain requirements like the previous possession of Palestinian nationality, proof of being registered residents of Israel since 1949, and continuation of it in 1952 (on the day of the law coming into effect), and were "in Israel, or in an area which became Israel territory after the establishment of the State, from the day of the establishment of the State to the day of the coming into force of this Law, or entered Israel legally during that period."

Another serious question engulfed the political sphere of the nation that manifested in the form of an Israeli political debate that questioned Israeli nationality in a deeper sense and how it is distinct from 'Jewish or Palestinian nationality.' Moreover, the domestic law of the nation that recognizes citizenship along the lines of ethnic affiliations and religion seems to play an important role as the nation has always acted reluctant regarding solving of conflicts between the religion and the franchise of citizenship. Thus, it should be noted that the registration imprinted on Israeli identity card is under the field le'om (nationality or ethnic affiliations). Till date, two law suits regarding this have been brought to light where citizens put forward questions regarding their true nationality. For instance, the first case was lodged by an activist and psychologist, Georges Tamarin in 1972 who asked the court to change his identification regarding nationality from Jew to Israeli. To this, the court ruled against him arguing that "there is no Israeli nation separate from the Jewish people." However, it needs to be mentioned that the Tel Aviv District Court, in 2011, granted Yoram Kaniuk's petition to do away with his classification as "Jewish" in his identification. A recent case regarding removal of the "Jewish" term in identification was that by Uzi Ornan in 2010 which was denied once again by the Supreme Court in 2013 as they voiced their concerns regarding upholding the nature and preservation of the Jewish state.(Ornan v. Ministry of the Interior , 2013) The wide belief is that a citizens' 'right to vote' is essential to the exercise of their membership but it necessitates a fewer number of "subjects" and "citizens." Nevertheless, in Israel, the notion of citizenship is surrounded by constant turmoil as the access to the franchise and the "requisites to active participation in the polity" varies man to man. It needs to be mentioned that in contemporary usage the distinctions between the "legal and political elements" borrow from each other. Thus, such a process reflects the problematic conception of Israeli citizenship. The complicated nature of Israeli citizenship is aggravated by the values embedded in the notions followed by the nation and is furthered by halakhah which is an integral part of it.

Israeli citizenship mentions three major routes through which one can apply to become a citizen of Israel. They are jus sanguinis — which is citizenship by descent; jus soli citizenship by place of birth for others; through Toshav Keva (permanent residency status). The citizenship law in Israel states that a person needs to meet at least one of the requirements stated by the government.(Nationality Law 5712-1952) They are:

- $\quad$ Those eligible for Israeli citizenship according to section 4A of the Law of Return;

- Children under 18 who are Israeli residents;

- Individuals whose citizenship was cancelled during childhood; 
- $\quad$ Permanent residents are married to Israeli citizens eligible for naturalization; permanent resident eligible for naturalization.

However, Israel claimed that citizenship ascertained 'by return' is the "primary means" for obtaining citizenship which was a departure from the usual practice of regarding "citizenship by birth" as the primary. In a speech the then Prime Minister David Ben-Gurion explained the Law of Return to the Knesset that "this law does not provide for the state to bestow the right to settle upon the Jew living abroad; it affirms that this right is inherent in him from the very fact of being a Jew; the state does not grant the right of return to Jews of the diaspora. This right preceded the state; this right built the state; its source is to be found in the historic and never broken connection between the Jewish people and the homeland."

The speech delivered by the former Prime Minister shows the heightened position awarded to Law of Return amidst Israeli citizens which by default gives primacy to citizenship ascertained 'by descent.' Another important aspect is that via Nationality Law, a Jew born in Israel is considered to have possessed citizenship by return. This shows that any Jew becomes a virtually automatic citizen of Israel leaving a non-Jew in a conundrum.(Qafisheh)

\section{LAW OF RETURN, 1950}

Israel is a Zionist state which aims to open immigration of world Jewry to promote the reconstruction of the Jewish state. A principal law in the sphere of citizenship is the Law of return, 1950 which was established as a central component of the basic law that claimed Israel as the nationstate of the Jewish people, in 2018. This fundamentally regulated immigration of Jews into Israel demanding nothing special from Jews regarding possession of citizenship. They could simply show up and attain citizenship without being considered as a threat to Jewish people. However, the Ministry of Interior may deny citizenship post verification and discovery of criminal conviction, mental issues, or religious conversion can lead to denial of citizenship. The government states that citizenship is granted "not only to Jews, but also to their non-Jewish grandchildren, children, and spouses." This was done to ensure that no family is broken and to provide a safe haven for non-Jewish people facing persecution as a result of their Jewish roots. The Law of Return maintains that people eligible for Aliyah (immigration into Israel) are referred to as Olim (Jews returning to Israel). Furthermore, it states that Aliyah shall be granted on the basis of Oleh's (singular of Olim) visa who has expressed the desire to settle in Israel unless the Minister of the Interior is satisfied with a cause on the basis of which the Oleh can be denied entry. This law also defines the term 'Jew' for the smooth functioning of it clarifying that such a person is someone "who was born of a Jewish mother or has become converted to Judaism and who is not a member of another religion."

Robert Friedman in his article 'The Law of Return: Ethnic Division in Israel', states that the introduction of this law pushed the nation into an ethnic turmoil inviting massive immigration from "Western Europe, the Middle East, and North Africa."(Friedman) The Jewish population of 650,000 in December 1947 increased to over 16 lakhs at the end of 1952. The population doubled in the ten years from 19491959 and quadrupled by 1964 acting as an impediment to the proper functioning of citizenship in an already troubled nation in this sphere. Thus, Israel is an immigrant society with ethnic diversity acting as the fundamental feature of existence where absorption and assimilation of the immigrants after 1948 was primarily achieved via hasty moves. Friedman claims that to understand the present ethnic divisions we need to understand Zionism and Jewish nationalism. The Zionists aspect of the law points out three basic values: firstly, it provides for a "symbolic identification for native born Jews" as the "Worldwide Jewry" is considered as "one people" and is entitled to Israeli citizenship. Secondly, the founders promoted an activist form of citizenship that promoted the participation of Jews in re-construction of the Jewish state. Finally, the laws regarding citizenship make a clear distinction between the Israeli Jews and non-Jews which is believed to be a deliberate attempt aimed at upholding Zionist ideology that claims Israel solely as a state for the Jewish people.

In 1977, Avraham Shama and Mark Iris noted that various debates and composition of the society are contributing factors to the existing ethnic dilemma. The waves of immigration from 1882 to 1948 were by no means homogenous. The statistics reveal that approximately one hundred and fifty thousand Jews entered the country following independence and dramatically altered the cultural character of the society. The author writes that during his first visit he was struck by the diversity of cultures and traditions making the contrast between the early settlers and the new immigrants vivid. Majority of the former was committed to socialist Zionism whereas the latter were selfselected and thus marking another distinction between them. These observations have been confirmed by Israeli social scientists like S. N. Eisenstadt in 1950, Judith Shuval 19501960 and by Shama and Iris. However, the situation of the nation can be said to be turning towards something better as the Sephardic community can now entertain the thought of providing their children with a good life, something that they could not imagine before. In conclusion, we can say that the Law of Return introduces real and particularistic problems for Israel as scholars believe it to be broad and 
narrow, all at once. This law aims at calling every Jew into Israel irrespective of the nation's strength and the geographic location and thereby poses as too broad. It is narrow in the sense that it fails to identify a large portion of the population or a vast number of immigrants relying solely on their descent reflecting the distinction between the majority and the minority of the nation. Israeli idea regarding citizenship runs diametrically opposite to the concept as it is largely about "shared and common status."

A major form of protest against the laws set in Israel explaining the parameters of citizenship has been 'renunciation of citizenship rights' providing the automatic right to immigrate into Israel on the grounds of Jewish descent. More than 100 Jews have renounced their 'natural right' to Israel in solidarity with Palestinians to whom the government has not extended anything as such with regards to citizenship.(Bevermen)However, it must be mentioned that due to a lack of information regarding effects of protest in the sphere of active citizenship held by the Jews, most of that data accumulated regarding it belongs to the 'right of return.' Massive protests have erupted in Tel Aviv, Israel in 2018 against a citizenship bill that aimed to uphold the Jewish character of the state by discriminating amongst the Jews and Palestinians holding legitimate Israeli citizenship. Critics confirmed that the non-Jewish citizens feared that they would be treated as second class citizens in their own home. The "nation-state bill" establishes Hebrew as the official language of Israel thereby downgrading the status of Arabic and claims the allegiance of non-Jewish people to the nation. A demonstrator Omar Sultan commented, "This law is against us, against the Arabic language, against peace, against our future in this land. We are the real people of this land." The protests highlighted not only the discriminatory nature of the bill but also the undemocratic step the nation would be taking.(Tens of thousands protest in Tel Aviv against 'nation-state law')

\section{INDIA AND CITIZENSHIP}

The government explains that Indian citizenship can be acquired by birth, descent, registration and naturalisation. There are a number of procedures and conditions for acquiring Indian citizenship as per the provisions of Citizenship Act, 1955. The constitution had initially given a great deal of importance to citizenship acquired via jus soli that gradually moved to the introduction of acquiring citizenship via jus sanguinis. However, it must be mentioned that the scenario was different in the beginning as one the pioneers of the Indian Constitution, namely, Sardar Vallabhbhai Patel voiced his concerns and stringent opposition for basing citizenship on descent. Nevertheless, this changed in the year of 1987 when the-then PM Rajiv
Gandhi, working under the pressure of Assamese nationalists and signed the Assam accord paving the way for citizenship by descent. The "natural right" of Hindus to become citizens of India had been a strong argument amongst constitutionalists at the beginning but the Constituent Assembly members at the end adopted a "secular definition of citizenship" and replaced the words that put forth religious connotations with secular ones. All the measures taken to do away with any kind of communal term was to promote a "political majority" that would exist solely on the basis "rational and secular principles." The Parliament, after discussing the citizenship bill, diverged from any kind of religious terminology thereby discarding the idea that 'Hindus are automatic citizens of the nation.' This move was followed by the National Citizenship Register (NRC) in 1951 which aimed to ensure the "secular rehabilitation" of the mass.

\subsection{Citizenship (Amendment) Act, the setting in India}

The Indian citizenship issue was far from being solved as major Hindu Nationalist Organisations, re-invented citizenship for political purposes which claimed that the Hindu citizens must be treated as "natural" citizens of India. Irrespective of being a minute force in the 1950s, these groups managed to stir up controversies with regards to this as religion since times immemorial has been a fundamental part of the society. Moreover, by invoking the age-old debate of 'majority and minority' these groups were successful in justifying their claims. A natural outcome of the Hindu nationalist beliefs manifested in the form of the Citizenship (Amendment) Act (CAA) 2019 that largely introduced religious and communal aspect into the society with regards to this, and posed as great stress on Hindutva as the basis of citizenship that aimed to create a Hindu nation. The aforementioned Act acts as an "exclusivist and ethnic" Hindu nationalist idea that seeks to establish the supremacy of the majority and awards 'second-class' status to the minority groups, mainly the Muslims . Furthermore, two other amendments to the Citizenship Law preferred jus sanguinis over jus soli and thereby substantiating to some extent the ethno-religious character emerging with regards to citizenship. The latest amendment to the citizenship law that has been a topic of contention among many does include other groups but it must be noted that the Constitution of the nation does not regard Sikhs, Jains, and Buddhists separate from the Hindus. It is speculated that Christians have been added recently to appease "certain" world leaders and Parsis added to provide this idea with a legitimate aspect to it. Mohan Bhagwat, the RSS chief, delivered three lectures on RSS's version of Hindutva in 2018 that successfully entangled the notion of citizenship with religious, cultural and ethnic understanding. In his speech, Bhagwat enumerated three basic principles of 
Hindutva that is "patriotism, glory of our ancestors, and respect for culture". The collective understanding is what constitutes India and according to him "India belongs to that." Also known as Hindu nationalism practiced by the overwhelming majority of the Indian population forms the broadest foundation for such motivation. Soviet scholars have stressed that secularism in modern India is neither irreligious nor atheistic and does not directly oppose Hinduism. Religion remains a form of social consciousness allowing bourgeois-nationalistic theories to exist. Hindutva, almost like the Zionist call for the Jews, aims to call the Hindus as it considers them an inseparable part of the ideology and the nation.(Mezentseva, 1988)

Citizenship law, administered by Part II of the Indian Constitution, namely, Article 5 to 11 , faced amendments in the years of 1986, 1992, 2003, 2005, 2015, and 2019. The 1986 amendment that was legislated after the Assam agitation and Assam Accord restricted citizenship by birth to children born of Indian citizens, stating at least one parent be Indian citizen for the child to qualify thereby, marking a serious restriction of the jus soli principle. This principle was further restricted by the 2003 Amendment that required no parent of the child to be an illegal migrant for the latter to qualify for citizenship. It also ruled that illegal migrants are ineligible for acquiring citizenship by registration or naturalisation. These are the ones that faced persecution or the fear of persecution in their respective countries resulting in their entry in India on or before 31 December 2014.

\subsection{Citizenship (Amendment) Act, 2019}

A landmark amendment has been the one of December 2003 when the National Democratic Alliance led by the Bharatiya Janata Party (BJP) passed the Citizenship (Amendment) Act, 2003 with far-reaching revisions, and added the notion of 'illegal migrants' making them ineligible to apply for citizenship which was to be followed for the future generations as well. Those immigrants could further be deported or jailed in case they travelled in India without valid documents. The Government of India created and maintained a National Register of Citizens from the 2003 Amendment. The bill enjoyed the support of parties like the Indian National Congress and the Left parties. Furthermore, BJP in its 2014 manifesto promised a haven for persecuted Hindus and leaders promised the state of Assam that they would get rid of Bangladeshis along with a promise for protection of Hindus fleeing religious persecution. Various comments pointed out that this move gave citizenship a new meaning as the deportation of illegal migrants was biased since illegal migrants who were non-Muslim could be excused whereas Muslims would be deported. Moreover, it should also be mentioned that the "minority communities" of Pakistan and Bangladesh were exempted from requirements of the Passport Act, 1920 and the Foreigners Act, 1946 which came into effect by 31 December 2014. In 2016, the BJP government moved an amendment to the citizenship law along with which the government also succeeded in its effort to update National Register of Citizens (NRC) in the state of Assam. The introduction of the amendment was, however, stalled as it was not passed by the Rajya Sabha. The BJP did, however, reiterate their promise to amend the act in its 2019 campaign to protect the minorities persecuted in the neighbouring countries or elsewhere. The 17th Lok Sabha cleared the citizenship (amendment) bill on 10 December 2019 post introduction by Amit Shah on 9 December 2019 and the Rajya Sabha passed the bill on 11 December 2019. Presidential assent on 12 December 2019 moved the contentious bill to the status of an act thereby coming into force on 10 January 2020. Moreover, the bill includes provision for cancellation of applications of Overseas Indian Card (OCI) or the holder being heard before the move.

This law entertains extremely discriminatory ideology which pits the majority against the minority. And, prima facie distinguishes amongst the mass on the basis of religion inviting a large number of criticism and debates questioning its validity and communal approach. An article makes its position clear by questioning the Act's constitutionality as it seems to be in violation of Article 14 of the Indian Constitution guaranteeing 'equality before the law' which prevents the government from arbitrary behaviour towards certain people. Nevertheless, even this right has limitations as the state is awarded powers to impose restrictions, but classifications need to be rational and just. Thus, even though the government can justify the inclusion of Pakistan and Bangladesh in the Act, Afghanistan's mention seems to be irrational as justification on the basis of settlement of members from undivided India seem to be flawed to a great extent. Moreover, one of the major arguments justifying this bill is that of the provision of a safe haven to illegal immigrants or those fleeing religious persecution, but, the fact that this bill disregards other minorities facing such violence belonging to neighbouring countries with which India shares her border poses as another question. Another confusing aspect of the bill is how it conveniently failed to include the "Ahmedyya Muslims" who are treated as nonMuslims in Pakistan strengthening the belief of several that this is majorly targeting people on the basis of descent. For now, the justification for such a bill stands flawed and is irrational at best. If the motive behind the CAA was to divide the society on the basis of religion, what it instant managed was to unite people from all walks of life, from different communities and social backgrounds. The movement against this Act has swelled across the country with Assam and other North-Eastern states dwelling in 
constant fear of loss of linguistic and cultural identities of indigenous communities and this fear became the basis of their agitation compounded by the threat of determination of citizenship on religious lines. These states have raised a red flag against Narendra Modi government's midnight tryst with its gene of Hindu Rashtra. It was their apprehension that this Bill will encourage a fresh influx of 'Banglaspeaking Hindu Bangladeshis' to Assam thereby overwhelming the Assamese and other ethnic language speakers of smaller nationalities. The passage of the Bill in the Rajya Sabha dashed all hopes of the regions' people that Parliament would come to their rescue by defeating the amendments to the Citizenship Law pushed by the ruling party, with apprehension starting to build up since the government pushed the citizenship bill in Parliament in 2016. In addition, the Supreme Court-mandated exercise of updating the NRC, 1951 with a cut-off date of 24 March 1971 was on full swing in Assam. Although this process of updating kept alive some hopes of implementation of the Assam Accord of 1985 that identifies all "illegal migrants" of Bangladesh, both Hindus and Muslims after this cut-off date. To their dismay with the ruling government and the Rashtriya Swayamsewak Sangh (RSS) trying to institutionalize their ideological position, shattered this hope by claiming Muslim migrants from Bangladesh, Pakistan, and Afghanistan as "infiltrators" and Hindu and other nonMuslim minorities as "refugees."

\subsection{Assam, the North East, and Bangladesh}

The state of Assam, Meghalaya, and Tripura saw unprecedented and spontaneous protests against the new citizenship laws, defying curfew and other prohibitory orders. They took out protest rallies, carried out flag march even though the Central Reserve Police Force resorted to laathi-charge (assault), fired bullets, and tear gas shells towards them. The protests sent a loud and clear message that the North-East does not approve the game plan of the government trying to tamper with the Preamble of the Constitution. Expansion of Inner Line Permit (ILP) area, however, presents a paradox: of India softening its International Borders with its Association of Southeast Asian Nations (ASEAN) neighbours, and Bangladesh and Bhutan to facilitate trade, commerce, and peoples' movement under the Act East and Neighborhood First policies but hardening the boundaries within the NorthEastern region and imposing restriction on the movement of people and goods within the region.

There has been assurance by the Central and the State governments that the Assamese have nothing to fear as they are protected constitutionally and legislatively under Clause 6 of the Assam Accord that seeks to protect, preserve, and promote their cultural, social, linguistic identity and heritage. However, the All Assam Students' Union and other organizations have rejected this Clause as they believe that this is to make them accept the burden of "illegal Bangladeshi migrants both Hindus and Muslims" from 1951-1971. The Assamese people, aware of the repercussion this new Citizenship (Amendment) Act would bring in, are therefore not ready to accept it as they believe that this would destroy the 'secular fundamentals' of the Constitution. By making attempts to make the cut-off date in the Assam Accord with a "communal Bill," the Modi government and the BJP-RSS combined were playing with fire. Former Rajya Sabha member Urkhaogwra Brahma said that this Act lacked clarity with regard to the exclusion of the 6th Schedule areas. Even as Assam continued to burn in a series of protest and mayhem, the Bill received the President's assent on the night of 12 December 2019 harnessing citizenship on the basis of religion. Going by the Act the cut-off date for eligibility of citizenship in India is 31 December 2014 after which any Hindu migrating to India from Bangladesh, Pakistan, and Afghanistan without valid travel documents will be treated as an "illegal migrant."(Assam NRC: What next for 1.9 million 'stateless' Indians?, 2019)

Moreover, India's neighbour, Bangladesh feared that NRC and $\mathrm{CAB}$ may trigger an exodus of Bengali speaking people from Assam thereby creating a 'Rohingya like crisis' and affecting India's relation with Bangladesh. The draft with 1.9 crore names was released on 31 December and 01 January 2018 and the concern gradually deepened following the second and the final draft published on 30 July 2018. It seemed as if a complicated process was adopted to deceive the vast majority. Of 3.29 crore applicants, 19 lakhs were excluded from the final NRC list published on 31 August 2019 scaring Bangladesh's civil society, commentators, and media as the ones excluded were mostly Bengali, Muslims, and Hindus. The tension was legitimate as there has been a decades-old campaign in Assam to drive out "Bengali migrants" most of whose ancestors have settled in Assam during the colonial era; and Assam's anti-Bengali agitation that claimed lives of more than 2000 people in Nellie in February 1983 followed by 13 other nearby villages in Assam's Nagaon district. According to some analyst, the $\mathrm{NRC}$ and $\mathrm{CAB}$ might pose a challenge to the pro-secular parties in power, with the Islamist groups making a big issue of the denial of citizenship to the Bengali Muslims in Assam. The political commentators from Bangladesh put forth that NRC and CAB are blight on India's humanitarian spirit that saw the country give shelter to 10 million Bangladeshis in 1971 and lent unequivocal support to Bangladesh's independence struggle.

\section{SOLIDARITY FOR A CAUSE: STUDENT PROTESTS AGAINST CAA}


The agitation against the Act was further provoked with students of Jamia Milia Islamia and Aligarh Muslim University (AMU) drawing impassioned support from students of all communities thereby leaving the Government and its security taking the help of barbaric assaults on the youngsters to control the chaos. The attacks captured not only the nation's attention but also the rest of the world through social media with students and youths using social media to start campaigns exacerbating the protest. The movement grew with more educational institutions being vandalized that resulted in the unification and solidarity amongst students and youths leaving the security in sheer bewilderment. According to Bharatiya Mazdoor Sangh (BMS), the situation post CAA would be like the one that existed after the demolition of the Babri Masjid. The protests over Indian Citizenship Law that is believed to be based on religion spread through student campuses as a result of which critics point out the Hindu Nationalist governments' idea conflicted with the secular republic. Historian Baruch Gitlis, remembering the day leading to the Holocaust, recalled how the German encountered his most dangerous enemy, the Jew, wherever he turned. The situation in India was almost synonymous to this occurrence. By controlling the narrative and by selective dissemination of footage that showed only the marginalized vandalizing public property, the pro-CAA protestors tried to gain a degree of acceptance for the use of brute force against them was successful in garnering sympathy from few. The protests also spread to Gorakhpur and Lucknow. Lucknow saw a suspension of the Internet for 6 days; 21 people were arrested in Gorakhpur and 1000 booked for various charges. In some places, the action of the police indicated that they wanted to fan tension rather than diffuse it. People from Kasaiwali Masjid as a mark of protest wore black bands. The police intervened even to this, the incident that later involved few youths who according to the law enforcers were interfering in the due process. Many innocents who were harmed and affected by the violence felt that widespread communal passion constructed via images and sound bites aimed at suspension of conscience, throwing out the reason and secure a mandate to act against a "common enemy." A fall out of these developments is 'ghettoism' in the state, their inability to have an open line of communication with the police and their erosion of trust in the justice system giving rise to steady and accumulated rage.

On 5 January, Jawaharlal Nehru University faced (JNU) unprecedented violence where many students and several members of the faculty were attacked by a large mob of unidentified assailants armed with stones and sticks. It should be mentioned that a student's hostel and a teacher's residential complex known as New Transit House (NTH) were specifically targeted by the mob. Violence carried by the mob was captured mainly on video where one showed a chilling image of men and a woman all masked holding rods and sticks on the premises of Sabarmati Hostel. Due to the absence of CCTV, the identities of the armed intruders remained a mystery. Along with the students, resident teachers from the NTH were trapped inside. Desperate messages for help were sent to the university's security, the police and university officials but remained futile. The wind shields of cars were smashed and Ambedkarites were targeted by the mob. Moreover, in Sabarmati hostel, the rooms of two Kashmiri students were vandalized and visually challenged student was beaten up. One of the JNU alumnae claimed that the government is deliberately doing all of this in Delhi and across India to polarize the environment and hamper Democracy and capitalizing on the Hindu-Muslim issue. Citizenship claims of six groups namely Hindu, Christians, Sikh, Buddhists or Parsi communities have been considered as "legitimate" and inherently "Indian" while other refugee groups or migrants are not. This bias instigated a nationwide protest with visuals of the vicious crackdown by the Delhi police on students and protesters. A number of former civil servants have pointed out that both the NPR and the NRC were unnecessary. In reply, the government launched "Jan Jagran" (People's Awareness) campaign to inform the mass about CAA. Abhijit Banerjee, a JNU student, explained the uncanny resemblance the attacks had and that they echoed "of the years when Germany was moving towards Nazi rule". The government has promised an investigation and informed the police to maintain order at the campus. Critics have pointed out that this legislation is unsecular and against the Indian constitution, but the government has claimed that this new law is intended to help "persecuted" minorities. After a month the police probe carried on with regards to the mob attack had zero answers.(Night Of The Jackals, 2020)

Many parts of India faced demonstrations, which include hundreds of student protestors clashing with the police in New Delhi. Tear gas was used on the protestors and more than 40 students were detained. Throughout the state, curfews were imposed to curtail violence. New Delhi witnessed a series of violence and protests over the Act with the Northeast Students' Union staging a protest at Jantar Mantar that showed people from various walks of life and across organization joined the stir. The CPI(M) Delhi also staged a process at the same venue who also staged a similar protest near Gandhi statue on the Parliament premises, with banners saying. "CAB waapis lo" (withdraw the CAB) and "dharm aadharit CAB nahichalega" (will not accept the $\mathrm{CAB}$ based on religion) .NajmaAkhtar told, "it is not expected of the police to enter the university and beat up students" thereby demanding an investigation. On the 
evening of 15 December 2019 when the students of Jamia called for a peace march, a hoard of police men came sprinting across the campus trying to break the imposing iron gates. The library glasses were shattered and tear gas shells were lobbed inside and students who were not a part of the protest were victimized. The misbehaviour continued with the resident students and not even the girls' hostels were off limits. The protests were felt inside the Muslimdominated neighbourhood of Okhla and Jamia Nagar nearby while Farah Naqvi, women's rights activist called this a Black Day in the history of India. Many students from Delhi University said that the right-wing students' group has tried to intimidate them for protesting against the citizenship law. The protest was also seen in the Ramjas College, where students who were protesting were asked to leave the country. Students who belonged to different universities marched from Mandi House to Jantar Mantar as a mark of protest. They raised slogans demanding Azaadi (freedom) from the new citizenship law and carried posters that read: "We stand united against CAA," "agar tum decent hotetohdissent kosamajhte" (if you were decent you would have understood dissent), "secularism up, communalism down down." The students also lauded posters at Shaheen Bagh and Jamia.

In West Bengal for days protests went on were students, non-political organization, and social rights groups rallied stealing the thunder from political parties. The violence in the state erupted on 13 December 2019 as Bengal saw massive vandalism with road blocks and disruption of railway connectivity to North Bengal. The situation led to the suspension of Internet activities in Murshidabad, Uttar Dinajpur, and parts of both 24 Parganas. Many tried to disguise themselves in skull caps and started pelting stones at trains trying to malign a particular community. 22 December 2019 saw students' rally from different universities and colleges that marched towards the BJP headquarters in Kolkata with students singing, rapping, doing poetry recitals and brief speeches, carrying posters of protests with added wit and colour. One thing became clear that the young of the country, the nation's future had raised, their weapons being the words of peace, solidarity, unity, laughter, and song with a spirit of unity and camaraderie becoming infectious. Protests have also occurred in Jadavpur University were a student collected the Master's degree and Gold Medal immediately after which tore the Bill. A number of activists, mostly college going girls, belonging to Feminists In Resistance (FIR) who just finished door to door campaign urging residents to protest against CAA were attacked.

Students of Indian Institute of Technology (IIT) Madras, the University of Madras, Madurai Kamaraj University and Pondicherry University staged dharnas (strike) and as the stir threatened to gather momentum the State then declared holidays for all educational institutions. A German student from the Department of Physics at IIT Madras was among the protesters in Chennai carrying a placard that went viral stating "1933 to 1945: We Have Been There." Protests were also seen in Pondicherry University when a student refused to accept her Gold Medal from the President of India. Protests have also taken place in Benaras Hindu University Uttar Pradesh, University of Hyderabad, Osmania University, and MANUU University. On 19 December 2019, Chandigarh saw a march of 700 students majorly from Punjab University accompanied by students from districts like Ambala and Patiala. On the same day, Manipur saw silent protests from the women vendors of Ima Market along with students. This time, students from Indian Institute of Management, All India Institute of Medical Science, and the private universities joined their counterparts followed by institutions in small-town India, to express solidarity with the students in Jamia.

The protest against CAA found even the Mumbaikars coming out in large numbers for rallies. The first rally took place in the historic 'August KrantiMaidan' with almost 25,000 people attending the demonstration. Some striking placards like "burey din wapaslao" (bring back the bad days); "what offends you more, my Hijab (heads scarf) or the Bindi (cosmetic) with my Hijab?" said a girl wearing a Hijab and a Bindi. The protest also saw student activists, intellectuals, corporate and government employees, concerned citizens, members of minority communities, few Hindi film personalities like Farhan Akhtar, Swara Bhaskar, Javed Jaffery, and large contingents of women. Mumbai saw two rallies on 27 December 2019.

The youth are voicing their demands thereby making it of political significance and challenging the government. The Hindutva forces ended up facing widespread resistance by the youth of the country who are leading this resistance. This undoubtedly is testimony to the importance of the public educational institutions in our national life be it Jamia Milia Islamia, AMU, JNU, Jadavpur University, or the Indian Statistical Institute. Given the commitment of the students to the secular and democratic character of our polity the future of our nation now appears to be safe regardless of any transient difficulties, it may face.

\section{SHAHEEN BAGH'S GROWING INFLUENCE AGAINST CAA}

The final nails were the scrapping of special status given to Jammu and Kashmir and the recent CAA-NRC which was met with severe resistance not by some dubious cleric but by veiled Muslim women. These women comprising of home makers, school teachers, college lecturers and professors, 
the old and the young - have emerged as the strongest rallying point against the CAA-NRC-NPR attracting international attention. The protest is conducted in the way of a peaceful and relentless dharna giving hope and courage to the women to carry on the fight. "If we do not sit here today we might have to sit in a detention tomorrow. So we will fight for our rights here and now. We will not allow Modi to change our Constitution. People of all religions cooperated to give us this constitution," said a protester. Another protester with her 20-day-old baby says, "If I did not protest, when my child grows up, he will ask me 'what were you doing when India was protesting against the CAA?' What will I say? I do not want my not to respect me or think of me as a coward." According to many, the government has portrayed that it is a fight between Muslims and the Government. However, this is not true. The protests were joined by people of many communities as it was evident in India Gate and Jantar Mantar and as many protesters claimed, "you [the Government] want to divide us. We will not let you."

The household roles are now reversed with husband and sons covering the household chores while the women sit on the dharna. Protesters often sang, 'SaareyJahan Se Achcha Hindustan Hamara'; 'Hum layeHainToofan Se KashtiNikalke'; HabibJalib's 'Dastoor'; they also recited 'Hum Dekhenge'. Each speech that was addressed here ended with cries of InquilabZindabad (Hail Revolution). Another most important aspect of this protest was, politicians of almost all hues have been kept out. The women also assured in the New Year lighting candles and singing the national anthem while holding the copies of Preamble in their hands pledging to uphold the Constitution of India. The elderly provided a boost to the strength of these women fighting against injustice, thereby leaving everybody stunned. "What do I have to lose by coming here? At the most I will die; but I will ensure that when my grandson or his children grow up, they will not have to give evidence of being Indians", said an elderly protester. Whereas another said, "media walonkohamarenaambhilenanahinaata.

Lekinwobhiyahaanhai.

Kuchhbaat

to

haihamareaeatejajmein" (media personnel cannot even pronounce our names. But even they are here. There is something remarkable about our protest). The protest slogan was "Kaagaznahidikhayenge" (we will not show any papers). Many "Shaheen Baghs" have also emerged with time. In Delhi, hundreds of women sat day in day out which was portrayed by the Government as one driven by Muslims alone but their constant attempt to create havoc were faltering. One of the iconic features of these protests had been its methods that even included cooking the Langar (community kitchen). Somehow the little-known locality
Shaheen Bagh suddenly became the landmark of the city's political protest, as the fear of an uncertain future to prove the nationality crept upon individuals and Indian Muslims in particular. Protests, mostly by women, have also erupted in Seelampur, Turkman Gate and Khureji. The steps of Jama Masjid have also turned into a protest site. Elsewhere, in India, women came out to protest along with Shaheen Bagh from Waseypur to Jaipur, from Allahabad, Kanpur, Etawah, and Lucknow to Patna and Gaya, from Azad Maidan in Mumbai to Park Circus maidan in Kolkata. The surprising fact being even in small towns like Gopalgunj and Kishangunj many Muslim women came out to protest. There has been an incidence of police brutality were the police took away the tents and blankets of the protesters, lodged FIRs against 60- odd women for rioting and inciting hostility between communities. Women protesters have felt traumatized and demanded that the police who were responsible for the violence be brought before the law. "... we are suffering mentally", said a protester on the police's botched-up action in the night to break the agitation. Tamil Nadu grabbed national attention as young activists expressed their dissent against CAA through kolams (art form) .

Women came from afar to participate in the protest constructing their very own Shaeen Bagh. The first among the "other Shaheen Baghs" was east Delhi's Khureji. The next site was Inderlok where the protesters got support from advocate MahmoodPracha, to set up tents and a small stage. These sites became a ground for young poets and protesters who fixated on how the authorities are trying to sell a Hindu-Muslim binary to confuse commoners. Women from Nizamuddin also poured into these protests. On 07 January 2020, 7 women led by AsmatJamil sat in protest at Kolkata's Park Circus maidan against the CAA-NRC-NPR. These women were independent of any political connections but were resolved to remain there until the controversial act was withdrawn. Asmat had urged women of Bengal to join her in the protest and surprisingly women from Birbhum, Murshidabad, Purulia, etc. began to join the protest in an act of solidarity. Students and young activists also arrived to support and extend their assistance to these women protesters. These students included students from Jadavpur University, Presidency University, and other places as well.

The Shaheen Baghs across the country will continue to chant Azaadi as the Muslim women come out of their pardah (curtain) of seclusion (White, 1977) into the political mainstream with no "patriarchy" leading them in search for justice. Women, in general, will now be known for their true identities: fighter for their own space and rights and no longer be seen as victims to matters that dominated public discourse. 


\section{DISCUSSION}

Citizenship has become a tool that is available easily at a state's disposal. Empirical data regarding the same revealed that its usage in manipulative forms to forward vested interests is completely left to one's cognizance. The availability of various reports in favour of the Israeli Law of Return as something legitimate and a structural necessity for unity of nation proves this point. However, websites have recently started to put forward the "discriminatory" aspect of the law. The provisions of this law were tested recently in 2011 when a homosexual couple made Aliyah to the nation. The couple made headlines when the Jewish man received citizenship but decisions by the ministry regarding his husband was delayed probably because he was catholic but was granted citizenship in a few months. In 2014, finally, the ministry welcomed immigrating same-sex couples. A poll that was conducted by Pew Forum in 2016 revealed that approximately $90 \%$ of Jewish Israelis claimed that the law should continue although in 2017 another survey brought to light only $25.2 \%$ considered it legitimate. A periodical claimed that despite the ongoing pandemic Israel is expected to see a spike in Aliyah. A little or no information is available about international ramifications of Law of Return. But thorough research argues that this Law may be assumed to be potentially illegal as Israel is bound by article 12(4) of ICCPR 66 that claims "no one shall be arbitrarily deprived of their right to enter his own country". The right of return remains an inalienable "Human Right" although there is still no action from the international community that has left the Palestinian refugee crisis as one of the largest and longest unresolved cases.

On the other hand, the Indian scenario was marked by 'objectivity' in journalism hoping to shield the perpetrators of the state violence by portraying the protesters as troublemakers. The evidence showed forces entering Jamia, breaking the CCTV cameras, assaulting unarmed students; and firing at protesters in Uttar Pradesh; many acts of, "selfdefence" was proved wrong. Due to such incapability, and a sheer lack responsibility of the leading media outlets; the protesters took matters in their own hands by resorting to social media. This was the new Hashtag Activism. Instagram feeds, Twitter, Facebook, WhatsApp groups experienced traffic of videos as students stranded in and around the troubled areas captured the brutality, first hand. \#SOSJAMIA \#SOSAMU \#SOSJNU remained trending for long. Social media remained evidence of history, like a book. The youths were the centre of this protest, and they experienced a solidarity circle to help those in need. This happened to be a counter to the propaganda journalism that had turned a blind eye towards the protesters. And both social media and the youth played a major role to communicate the global community.

This protest received international attention with major headlines: "Protests spread across India over divisive citizenship bill" or "As Protests Rage, Is India Moving Closer to Becoming a Hindu Nation?.'The U.S. Commission on International Religious Freedom (USCIRF) was deeply troubled by the passage of this Bill as they believed it runs counter to India's rich history of secular pluralism. The United Kingdom hoped that the Indian government addresses the concerns of the people over CAA and "regrets" over violent protests that took place. The United States and Canada have issued travel warnings for people visiting India's North-East telling their citizens to "exercise caution" if travelling to the region. MP David Shoebridge, of Australia, shows deep concern regarding India's implementation of CAA claiming that it discriminates on the grounds of religion and revokes citizenship of religious minorities resulting in statelessness for many vulnerable putting forth also the police violence during the protest. He urged for a renegotiation of trade agreements between India and Australia so that it includes a human rights clause. However, Russia, France, and the Maldives consider this an internal matter of India. Many countries like Pakistan, Afghanistan, Kuwait, and Bahrain have termed this law as discriminatory and have shown deep concerns about the ramifications that would follow on its implementation. The UN High Commissioner for Human Rights criticised the Act for being "fundamentally discriminatory in nature", as it appears to undermine India's commitment to equality before the law.

\section{CONCLUSION}

An inference can be drawn between the two nations that reveal how the jus soli principle has been side tracked by the jus sanguinis principle. The Israeli government was not in favour of genetic tests but that seemed to be changing in the recent times with cases like that of the Yakerson, the family who is settled in Russia had to go through such tests when their daughter Masha Yakerson, hoped to apply for a free trip to Israel. The father claimed the policy to be 'blatant racism towards Russian Jews' as participation by others carries less strict laws when asked to prove their 'Jewishness'. A similar case made headlines in India after a retired army officer, Md. Sanaullah was sent to detention camp as he was declared a 'foreigner' by Assam's Foreigners' Tribunal that claimed discrepancies in the submitted documents.

Nevertheless, a major difference between Israel and India to-date is the democratic structure of the two nations. India has always been a 'puzzle'(Lijhart, The Puzzle of Indian 
Democracy: A Consociational Interpretation, 1996) to scholars reviewing its democratic structure. They have concluded that no matter its 'deviant' nature, India can be largely termed as a consociational democracy. In Israel, there exists a major cleavage between the Jews and Arabs the overwhelming presence of the former makes it largely a Jewish state. Unlike India, the absence of two major consociational principles, a grand coalition and dubious balance of power makes it a semi-consociational democracy.(Lijhart, Democracy in Plural Societies: A comparative exploration, 1977)

The topic covered, is extremely significant as the issue of citizenship is emerging as one of the most controversial topics that claim our immediate attention. The question put forward at the beginning of this paper has been answered with the hopes that there would be a rise of critical thinking with regards to this. Countries, probably, to disregard refugees and institutionalize citizenship norms introduced a number of laws in this sphere that has turned largely communal and discriminatory. We hope, for a better tomorrow that repudiate discrimination based on religion and uphold the principle of sovereignty.

\section{REFERENCES}

[1] Assam NRC: What next for 1.9 million 'stateless' Indians? (2019). Retrieved 2021, from BBC: https://www.bbc.com/news/world-asia-india-49520593

[2] Bellemy, R. (2008). Citizenship: a very short introduction. New York: Oxford University Press.

[3] Bevermen, I. (n.d.). Renouncing Citizenship as Protest: Reflections by a Jewish Israeli Ethnographer.

[4] Edelman, M. (1998). Who is an Israeli? "Halakhah" and citizenship in the Jewish state.

[5] Friedman, C. R. (n.d.). The Law of Return: Ethnic Division in Israel. The Antioch Review, 47-59.

[6] Georges Raphael Tamarin v. the State of Israel , C.A. 630/70 (1972).

[7] Lijhart, A. (1977). Democracy in Plural Societies: A comparative exploration. Yale University Press.

[8] Lijhart, A. (1996). The Puzzle of Indian Democracy: A Consociational Interpretation. American Political Science Review.

[9] Marshall, T. H., \& Bottomore, T. (1949). Citizenship and Social Class. Cambridge University Press.

[10] Mezentseva, O. V. (1988). Ideological Struggle in Modern India: implications of Hinduism. Nauka Publisher.

[11] Nationality Law 5712-1952. (n.d.). Retrieved January 2021, from https://www.knesset.gov.il/review/data/eng/law/kns2_nation ality_eng.pdf

[12] Nesis, L. S. (n.d.). Who Is a Jew? Shalit v. Minister of Interior et al. The Law of Return (Amendment No. 2), 1970. Manitoba Law Journal.

[13] Night Of The Jackals. (2020, January 31). Frontline.
[14] Ornan v. Ministry of the Interior, C.A. 8573/08 (2013).

[15] Qafisheh, M. (n.d.). IV Palestinian Citizenship Order 1925. In The International Law Foundations of Palestinian Nationality (pp. 75-85). BRILL.

[16] Tens of thousands protest in Tel Aviv against 'nation-state law'. (n.d.). Al Jazeera.

[17] White, E. H. (1977). Purdah.

ISSN: 2456-7620 